\title{
DID NINETEENTH CENTURY MARINE VERTEBRATE FOSSIL DISCOVERIES INFLUENCE SEA SERPENT REPORTS?
}

\author{
C. G. M. PAXTON \\ Centre for Research into Ecological and Environmental Modelling \\ University of St Andrews, The Observatory, Buchanan Gardens \\ St Andrews, Fife KY16 9LZ \\ UNITED KINGDOM \\ cgp2@st-andrews.ac.uk \\ D. NAISH \\ Ocean and Earth Science, National Oceanography Centre Southampton \\ University of Southampton \\ Southampton $\mathrm{SO} 143 \mathrm{ZH}$ \\ UNITED KINGDOM
}

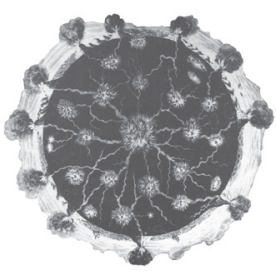

Earth Sciences History Vol. 38, No. 1, 2019 pp. $16-27$

\begin{abstract}
Here we test the hypothesis, first suggested by L. Sprague De Camp in 1968, that "After Mesozoic reptiles became well-known, reports of sea serpents, which until then had tended towards the serpentine, began to describe the monster as more and more resembling a Mesozoic marine reptile like a plesiosaur or a mosasaur." This statement generates a number of testable specific hypotheses, namely: 1) there was a decline in reports where the body was described as serpent or eel-like; 2) there was an increase in reports with necks (a feature of plesiosaurs) or reports that mentioned plesiosaurs; and 3) there was an increase in mosasaur-like reports. Over the last 200 years, there is indeed evidence of a decline in serpentiform sea serpent reports and an increase in the proportion of reports with necks but there is no evidence for an increase in the proportion of mosasaur-like reports. However, witnesses only began to unequivocally compare sea serpents to prehistoric reptiles in the late nineteenth century, some fifty years after the suggestion was first made by naturalists.
\end{abstract}

Keywords: sea monster, ichthyosaurs, Ichthyopterygia, cryptozoology, saurian doi: 10.17704/1944-6178-38.1.16

\section{INTRODUCTION}

In the autumn of 1848 , British newspapers were gripped by the account of a sea serpent seen by the officers and crew of the corvette H.M.S. Daedalus in the South Atlantic the previous May (Anonymous $1848 \mathrm{a} ; 1848 \mathrm{~b}$ ). Immediately there was debate as to what had been seen (see Figure 1; DSE 1848; F.G.S. 1848; Morries-Stirling 1848; Naturalist 1848; Owen 1848), as well as extensive correspondence in Volume 6 of the Zoologist (e.g. Cogswell 1848; Drummond 1848 etc.). This debate has continued to the present day (Oudemans 1892; Gould 1930; Heuvelmans 1968; Galbreath 2015; Naish 2017). In a 1968 contribution to the dispute, science fiction writer and science popularizer L. Sprague de Camp suggested a canoe, possibly attached as flotsam to a whale, as the cause of the Daedalus sighting (de Camp 1968, 1983). In fact, such a suggestion had already been made humorously 110 years before by Punch magazine regarding the sea serpent reported by H.M.S. Plumper in 1849 (Bowbell 1849).

De Camp (1968, 1983, p. 178-190) went on to suggest that "After Mesozoic reptiles became well-known, reports of sea serpents, which until then had tended towards the serpentine, began to describe the monster as more and more resembling a Mesozoic marine reptile like a plesiosaur or a mosasaur." De Camp gave neither evidence nor a specific time frame for this assertion, though from context it seems reasonable to assume he meant the nineteenth century. Such a trend has been mentioned by some sceptical writers on the sea serpent (e.g. Loxton and 
Prothero 2013; Naish 2017) but has never been verified. This suggestion is of interest in itself but is also interesting as an example of what might be regarded as a case where mainstream scientific discovery influences the interpretations of witnesses, and in turn the advocates of a scientifically 'marginal' position, i.e. sea serpent existence, in the nineteenth century (Lyons 2010). As an electronic database of sea serpent reports has now been assembled (see Paxton 2009; Paxton \& Shine 2016 for details), de Camp's suggestion can be formally tested.

\section{HISTORICAL BACKGROUND}

Loxton and Prothero (2013) and Lyons (2010) provided outlines of how early vertebrate palaeontology was relevant to ideas about sea serpents. Fossils of Mesozoic marine reptiles were known from the seventeenth century (Howe et al. 1981; Ellis 2003) but consisted predominantly of fragmentary, difficult-to-interpret remains. Fully articulated skeletons were only reconstructed from the 1820s (e.g. Conybeare 1824). Robert Bakewell (1833a) first proposed ichthyosaurs as potential candidates for sea serpents but in a footnote to the edited American edition of Bakewell (1833b, p. 214), Benjamin Silliman (1779-1864) suggested that plesiosaurs might provide a better explanation. Mosasaurs were not suggested as a hypothesis for extant sea serpents until (implicitly) 1892 (Hutchinson pp. 121-122) and more explicitly by Anonymous (1896) and Lucas (1901).

In order that new fossil discoveries might influence sea serpent witnesses, such fossils would have to be on display or made familiar to the public via the appearance of reconstructions, either as pictures or models. While much of this story involves discoveries from southern England, the French procurement in 1795 of the 'Great Fossil Animal of Maastricht' - the original Mosasaurus (Mulder 2004) - may potentially be significant. However, while considered by some scientists (most famously Georges Cuvier) as clear evidence for the former existence of gigantic, sea-going lizards akin to extant monitors, it is difficult to determine how familiar and influential this fossil was to people at large, especially in that it consisted of partial jaws and not of any finds indicative of total size or shape, and that renditions of its appearance in life were not made familiar to the public.

In England, fragmentary fossils such as partial skulls, isolated vertebrae and limb elements were included in biological and geological collections maintained both for teaching and public display as early as the 1760 s; none of the fossils concerned were complete enough to give people a clear view of the animals involved and were mostly considered to be the remains of ancient fishes or crocodile-like animals (Howe et al. 1981; Evans 2010). However, at least one substantial, large ichthyosaur specimen from southern England-a 5 meter long specimen of Temnodontosaurus - was on public display in William Bullock's London Museum of Natural History in Piccadilly between 1814 and 1819. Whitby museum had the Jurassic marine crocodylomorph Steneosaurus bollensis on display by the late 1820s (Lomax and Trevelyan 2010), but it was otherwise not until the 1830s that British ichthyosaurs and plesiosaurs were on public display (McGowan 2001; Taylor 2016).

Pictorial reconstructions of the new fossil marine reptiles were also available from the 1830s, notably the print Duria antiquior by Henry De la Beche (1796-1855) and various images derived from it (see Rudwick 1992 for a discussion). De la Beche also illustrated an ichthyosaur and plesiosaur in the third edition of his Geological Manual (1833). However, Rudwick (1992) has argued that more widespread dissemination of Mesozoic reptile morphology came later with the illustrations of such publications as Penny Magazine, aimed at the time (the 1830s) at the general public rather than geologists alone. Soon after, Thomas Hawkins produced the Memoirs of the Ichthyosauri and Plesiosauri (1834) and the Book of Great Sea-Dragons (1840) illustrated by artists John Samuelson Templeton (?-circa 1857) and John Martin (1789-1854), respectively (see Rudwick 1992 for a history). The latter, one of the most popular British artists of his generation (Myrone 2011), would illustrate highly stylised Mesozoic marine reptiles a number of times (Rudwick 1992). 
The general literate public's knowledge of Mesozoic sea reptiles can also be crudely assessed based on their first appearance in the mass media. The first mention of plesiosaurs and ichthyosaurs occurred in The Times (London) in 1829 (an anonymous reprinted account of a discovery by Mary Anning) and 1834 (a letter by $\Phi \mathrm{I} \Lambda \mathrm{O} \Sigma \mathrm{ATPO} \Sigma$ complaining that an ichthyosaur specimen had not yet been shown at the British Museum), respectively. Mosasaurs were first mentioned in 1882 (Anonymous). The first mention of ichthyosaurs and plesiosaurs in Punch occurred in the cartoon shown in Figure 1 in 1848, but this specific appearance could only make sense to Punch's readership if there was already prior familiarity with Mesozoic marine animals.

\section{RECREATIONS IN NATURAL HISTORY.}

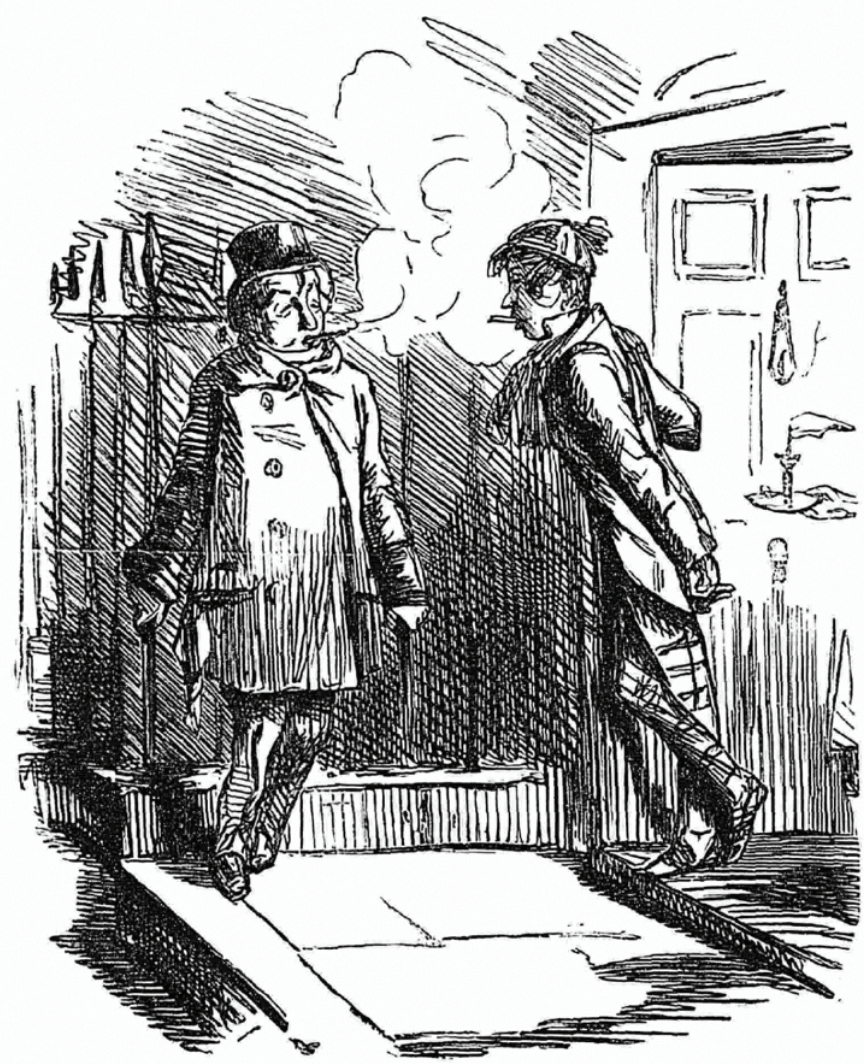

Figure 1. A cartoon from the humour magazine Punch 18 November 1848, p. 214, in the aftermath of the H.M.S. Daedalus sighting of a sea serpent in the South Atlantic. Reproduced by permission of the National Library of Scotland.

First Naturalist. "What! The S-S-She-SHer-Fent A-AN (Hic) ICH (HIC) tHrosauros? Nonsue-ENse!"

Second Naturalist. " Who said Ich-(Hic) Ichthy-0-Saurus? I said a (uic) Plesio-(III) Saurus plainenuff."

Further popularisation of the concept of extinct sea dragons came with such events as the unveiling of the life-sized prehistoric animal displays at Bromley in 1854 associated with the move of the Crystal Palace from Hyde Park (Doyle and Robinson 1993), the publication of Jules Verne's Voyage au Centre de la Terre (Verne 1864), and its first English translation (1872) with its battle of an ichthyosaur and plesiosaur. Late Victorian books on various topics such as geology (Figuer 1863), zoological mysteries (Gosse 1862), prehistoric life (Hutchinson 1892) and sea mysteries (Van Derwoort 1884) would often illustrate marine reptiles and such images would often be indiscriminately copied from publication to publication (Charles Paxton, pers. obs.). The large spectacular North American mosasaurs and plesiosaurs started going on display from the 
1870s onwards (Spamer et al. 1995, p. 146; Anonymous 1891). By this time exciting marine reptile fossil discoveries were being regularly documented American newspapers (e.g. Anonymous 1896; Anonymous 1894; Anonymous 1873).

However, not all nineteenth century sea serpents were associated with extinct reptiles. In 1845, showman Albert C. Koch (1804-1867) exhibited a 114 foot long fossil sea serpent under the name Hydrarchos Sillimanni (sic) in New York. H. Sillimanni was quickly exposed (the same year) as a composite of one or more archaic whale specimens (Wyman 1848). This is often stated (e.g. Oudemans 1892; Heuvelmans 1968; Loxton and Prothero 2013) to be Basilosaurus cetoides described from fossils by Richard Harlan (1834) but recognised as a mammal by Owen (1839); actually, however, Wyman (1848) made a direct comparison of Hydrarchos with the archaic whale Dorudon only, and was uncertain about the relationship between Basilosaurus and Dorudon. Koch marketed his Hydrarchos exhibition in both America and Germany as both an extinct sea serpent and as an identity for the extant sea serpent (Reippell 2017). A very well informed observer of palaeontology might have had a fossil whale as a model for the sea serpent as opposed to any extinct marine reptile.

It is therefore clear that from the late 1840s (and possibly earlier), a section of the literate general public of the United Kingdom, France, the Germanophone countries (where many of the new geological discoveries were popularised (see Rudwick 1992)) and the USA would have had some visual image of extinct marine megafauna, albeit at a proportion far lower than today. Literacy rates for males and females in Britain in 1840 have been estimated at $67 \%$ and $51 \%$ respectively (Altick 1957). Furthermore, not all people capable of reading would have had access to the relevant media. While de Camp's statement is not wholly unfounded, recognition of prehistoric marine life at the levels associated today both with higher levels of literacy (e.g. an OECD (2018) average of 98.6\%) and an almost universal access to television/film would not be present.

Meanwhile, sea monsters continued to be reported. Figure 2 gives the breakdown of reports known to us by year of encounter and by year when the report was made. There can be a substantial lag between encounter and report, and the dates of many reports are unknown. Note that - in contrast to what has been implicitly suggested by Loxton and Prothero (2013) and Lyons (2010) - there appears to be no steady increase in sea serpent reports in the nineteenth century, assuming the database reflects the population of reports. A peak in reporting occurred in 18171818 with reports from New England and there was a rise in reports from 1870 onwards. The explanation for this distribution is clearly not the timing of the discoveries of extinct marine reptiles; this is an issue that will be addressed in future work.

\section{DATA}

The available data consist of 1688 historical reports of sea monsters from 1543 events collected by the first author where the features of the reports have been classified into a database. Previous work on this dataset can be found in Paxton (2009) and Paxton and Shine (2016). The accounts were from various primary and secondary sources including books, newspaper accounts and firsthand testimony personally collected by the first author. Examples of the reports can be found in Heuvelmans (1968) or Oudemans (1892). The first-hand reports go back as far as the sixteenth century. Reports were required to mention objects interpreted by the witness as the part of the body of an unknown animal seen at the surface of the water. It is not known if all the reports are truthful or indeed necessarily of living animals. Nor can it be known if the witnesses have interpreted anatomy correctly. Exposed and admitted hoaxes or absolutely known misidentifications were omitted from the dataset. Suspected hoaxes or misidentifications were not. Therefore, we make no overall claims as to the truthfulness of the reports under consideration. A single event can generate several reports from different witnesses or the same witness (see 


\section{a) Year of Encounter}

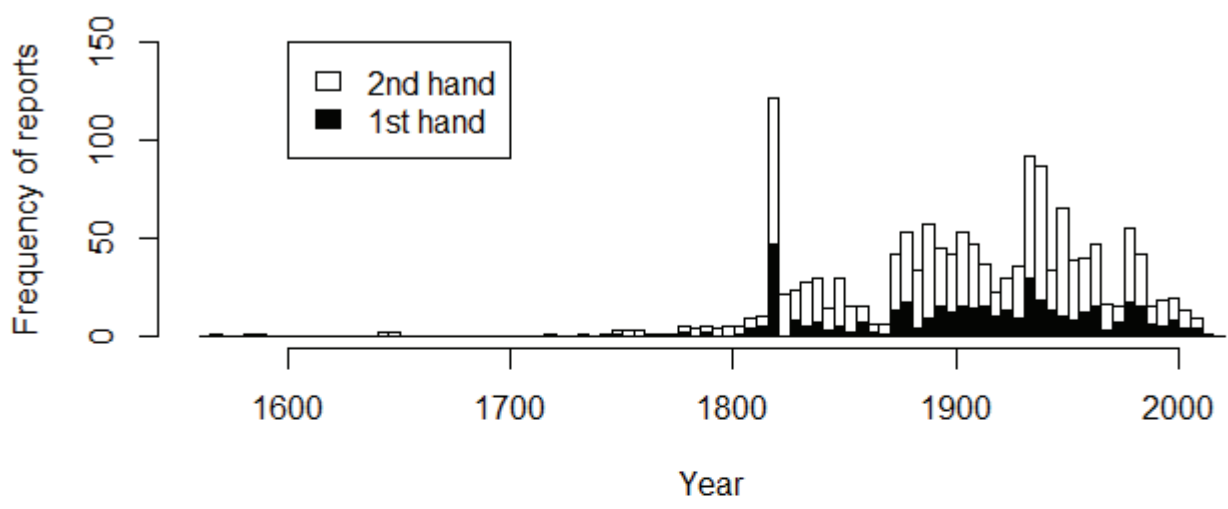

b) Year of Report

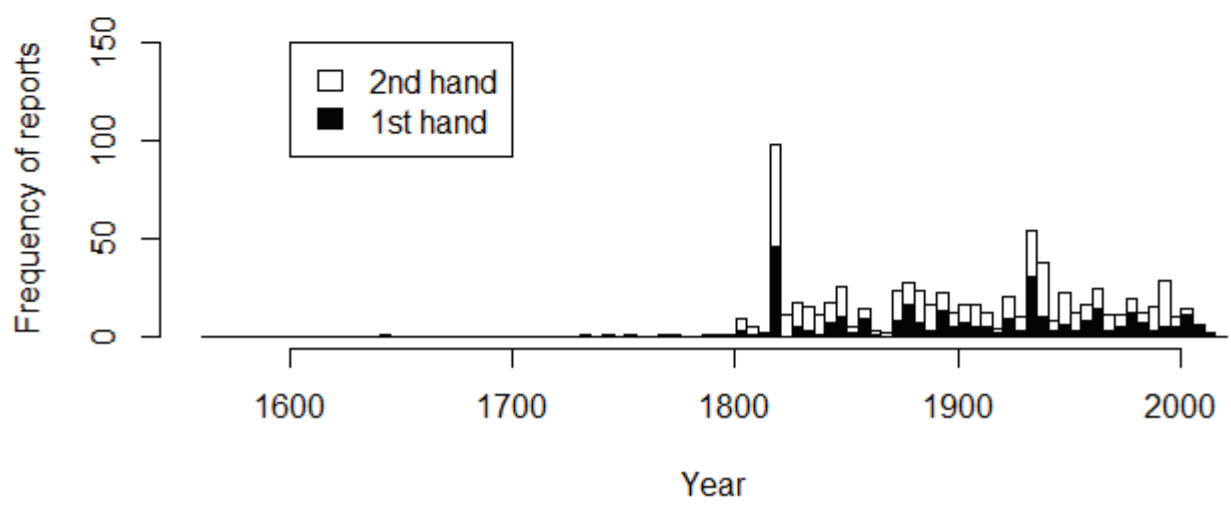

Figure 2. Frequency of sea monster reports in the database summed per 5 years. Above: By year of encounter $(n=$ 1492). Below: by the year in which the report was made $(n=745)$. Only one report per encounter is counted

Paxton and Shine 2016). For any given encounter, therefore, the single report with the most relevant information was extracted to ensure statistical independence. The data are non-randomly distributed in space and time and are clearly biased in favour of English language sources: predominantly the British Isles, United States of America, and Canada, these making up 97\% of the total 1543 independent available reports. Geographically, the database is biased towards the north Atlantic (61\% of reports) but does contain reports from all around the world. Not all reports had associated dates. Reports were considered in two data sets: first-hand reports and then first and second-hand reports combined (see shadings in Figure 2). First-hand accounts (i.e. accounts which are verbatim from witnesses and/or witnesses' drawings) were used by preference. It should be stressed that the statistical conclusions made here are about the characteristics of the population of monster reports, not of monsters themselves. The reports were collected, often initially by others, in ignorance of the hypotheses under consideration here (see below) so should be unbiased with regard to those hypotheses. There may well be temporal biases in the collection of reports but it seems reasonable to assume that the pattern in Figure 2 broadly reflects the actual frequency of reports in the English speaking world, especially given that the second peak is at 1930-1934 
and thus covers the renewed popularity in aquatic monsters generated by worldwide interest in the Loch Ness monster in 1933.

\section{ANALYSIS}

De Camp's suggestion generates three specific hypotheses:

1. The proportion of reports where the body is explicitly described as serpentiform should decline over time. Likewise, the proportion of non-serpentine reptile reports should increase.

2. As a long neck is the most obvious feature of a plesiosaurian sea monster, the proportion of reports with reported necks should increase over time.

3. De Camp's mosasaur suggestion is hard to formalise as it is difficult to identify a particular feature that would distinguish a mosasaur from a crocodylomorph, for example, to the casual observer. Nevertheless, we here consider the trend in the proportion of crocodile-like reports, assuming that it would be favoured description were a naïve witnesses to describe a mosasaur if they saw one.

Given the above hypotheses, two features from the collected reports are of most interest: namely, how the overall body shape was described and whether an obvious neck was described as present. Overall body form in sea monster reports can be described in a variety of ways: they might suggest that the animal is essentially amorphous, might compare it to man-made objects (e.g. wheels, pillars, posts etc.), or to actual animals, including ducks and even 'saurians'. Of course, the same metaphor or simile may not be used by witnesses in the same way but, on average, reports that are described as serpentiform, for example, would presumably be more snake-like than reports that are not described as serpentiform. Overall body descriptions were summarised and binned as shown in Table 1. The term 'plesiosaur' is here used to refer to the clade palaeontologists refer to

Table 1. Body form descriptors and their summarised names.

\section{Descriptors as used by witnesses}

Eel, snake, worm, sea serpent, cobra anaconda, cylindrical, hose, etc.

Lizard, crocodile, alligator, saurian, reptilian, dragon, etc., as distinct from serpent.

Body thicker than neck, prehistoric animal, dinosaur, plesiosaur, ichthyosaur, Sauropterygia.

Body described as a pillar, pole, Pillar/pole finger or similar.

Other descriptors
Serpentiform

Lizard/alligator

Plesiosaur

\author{
Pillar/pole
}

Other

\section{Other comments}

Only classified if the body-form stated to be like a serpent etc. rather than the whole encounter being described as being with a sea serpent.

Presumably, this category for some witnesses might have included animals which other witnesses might have referred to as 'dinosaurs' etc.

The sole 'ichthyosaur' described report is also included here.

All descriptions of vertical bodies go here.

A catch-all for all other body descriptors or encounters where no description was given. 
as Plesiosauria; likewise, 'ichthyosaur' is used for Ichthyosauria/Ichthyopterygia and 'mosasaur' for Mosasauridae. As cultural influences on reports were of interest here, only year of report rather than year of encounter was primarily considered in the following analyses. Two features of the reports were of interest: namely how the overall body shape was described and whether an obvious neck was described as present.

Two statistical analyses were undertaken in the statistical programming environment $R$ (v. 3.4.4.) using the $R$ library VGAM (Yee 2008). In the first analysis, the proportion of reports with each of the five body descriptors in Table 1 were fitted as a multinomial vectorized generalized linear model (VGLM) with Year as a predictor and with the dependent data given as a matrix of counts. In the second analysis, the proportion of reports where necks were reported were modelled as a binomial generalized linear model (GLM) again with Year as a predictor and the counts supplied as a matrix. The aim in each of the two cases was to detect a temporal trend in the proportion of reports showing the traits of interest in the direction predicted by Sprague de Camp's hypotheses. Data were fitted from years 1801 to 2011. Residuals were checked for independence and uncertainty was estimated in the VGLM case by the use of a nonparametric bootstrap (Davison and Hinckley 1997).

\section{RESULTS}

Approximately $41 \%$ of the distinct dated 306 first-hand accounts have body descriptors and 25\% of the dated 745 first and second-hand accounts combined have body descriptors. Approximately $30 \%$ of first-hand and $17 \%$ of all dated accounts mentioned the neck as present or absent. Firsthand reports have more described features than second-hand accounts across the two descriptors considered here $58 \%$ of first-hand accounts have one or more descriptors versus $16 \%$ of all second-hand reports).

Direct allusions to prehistoric monsters by witnesses mostly occur in the late nineteenth century. In 1834, a sea monster (in fact from its description almost certainly a whale shark) was reported in the Bay of Bengal by one Lt Foley (1835). He then went on to say "May it not be the Plesiosaurus or a species of that fish (sic), known to have existed formerly in the waters of the ocean". This account was also reprinted in newspapers (e.g. Foley 1836). The first allusion to a sea serpent looking like a crocodylomorph occurs in 1849 when Edward Newman (the editor of The Zoologist) inquired of a sea serpent witness - Captain George Hope of H.M.S. Fly-whether he was "acquainted with those remarkable fossil animals, Ichthyosauri and Plesiosauri . . . and I cannot find he had heard of them; the alligator being the only animal he mentioned as bearing a partial similarity to the one in question." An anonymous officer of H.M.S. Daedalus commented 10 years after the event "My impression was that it was rather of a lizard than a serpentine character" (Anonymous 1858) which might have been a reference to a prehistoric saurian. The first direct allusion by a witness to an ichthyosaur is in Lawrence (1884), "If such a thing as an ichthyosaurus is extant, I should think this creature to be one of the same family". The term "Sauropterygian"- - referring to the large reptile group that includes plesiosaurs and a number of relatively obscure groups, among them the nothosaurs and placodonts of the Triassic - was used to describe a sighting in 1913 in a letter written to the zoologist and sea serpent enthusiast Anthonie Oudemans by the $2^{\text {nd }}$ Officer of the steamer Corinthian: "Zoologically speaking I got a good view of the creature when diving, I could only describe it as identical with the Sauropterygia" (Batchelor 1913). To our knowledge no witness has ever compared a sea serpent to a mosasaur.

In each of the two statistical tests for trends in time, a resolution of ten years was chosen to create the proportions such that independence of the residuals could be demonstrated and there were sufficient reports to produce not widely fluctuating proportions due to small sample sizes. Figure 3 gives the proportion of all first-hand $(n=306)$ and all first-hand and second-hand combined (bottom, $\mathrm{n}=745$ ) dated encounters with references to serpentiform shape, pillar/post comparisons, allusions to extant reptiles and dragons, and allusions to prehistoric marine reptiles. 
The data are illustrated from 1781 although there is a paucity of data in the eighteenth century. The fit of the models fitted to two century's data is also shown. There is no evidence of any trend in any body-form proportion except a decline in the proportion of serpentiform reports (first hand reports: $\chi^{2}=23.3, \mathrm{df}=1, \mathrm{P}<0.001$, all reports: $\chi^{2}=24.2, \mathrm{df}=1, \mathrm{P}<0.001$, likelihood ratio test of the year regression versus an intercept only regression).

There is an increase in the proportion of sightings with reported necks since 1800 (firsthand reports only: $\chi^{2}=22.8, \mathrm{df}=1, \mathrm{P}<0.001$, all reports: $\chi^{2}=22.8, \mathrm{df}=1, \mathrm{P}=0.001$, right column in Figure 3 , likelihood ratio test of the year regression versus an intercept only regression). It should be mentioned that there is one second-hand neck sighting from 1786 (Figure 3 lower right), the only sighting in the database from that decade.
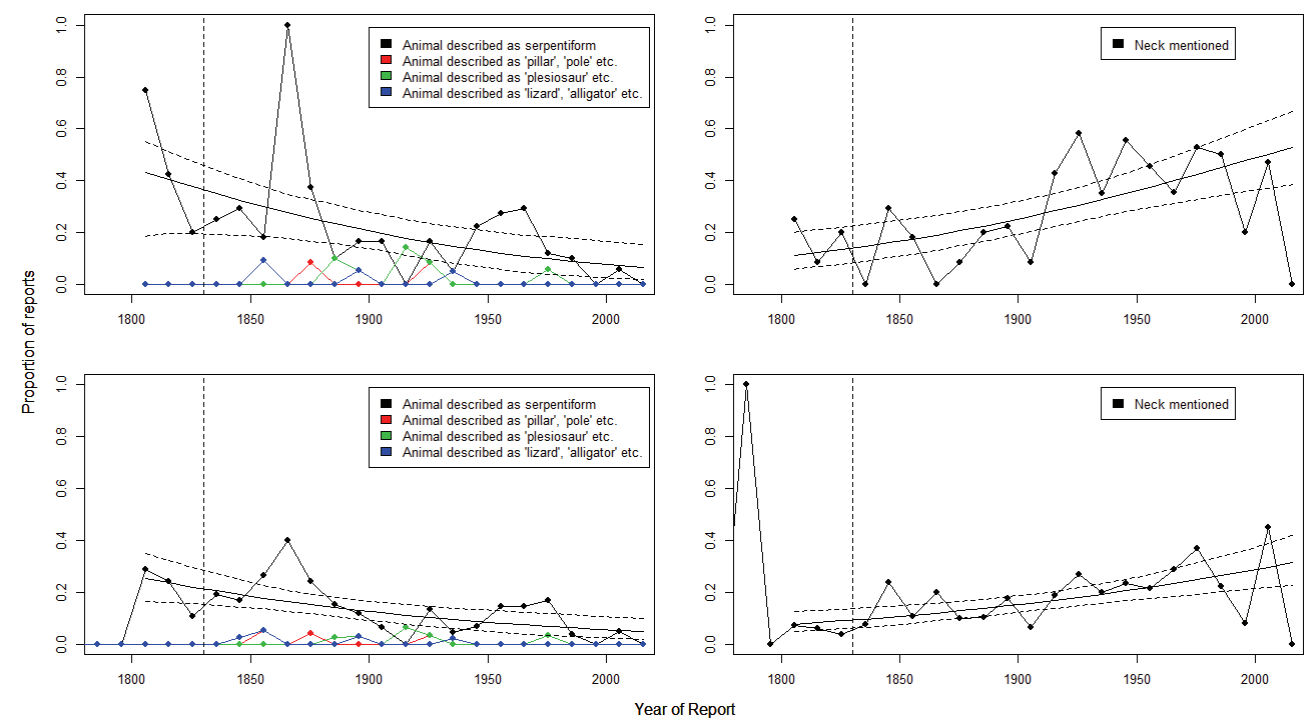

Figure 3. Proportions of top row: first-hand reports and bottom row: all reports by body descriptors (left column) and reported neck (right column). Solid lines with dots: actual data. Solid line without dots: fits from a model. Dashed lines: $99 \%$ confidence intervals on model fits. For clarity only model fits from the proportion of serpentiform reports shown.

Data from 1781 where available, model fit from 1801. Vertical dashed line: 1830.

As a final test, assuming by "plesiosaur or a mosasaur", de Camp meant all non-serpentine reptilian/dragon accounts increasing in number, all non-serpentine reptile were combined and their trend considered. There was no evidence for a trend in either first-hand $\left(\chi^{2}=0.12, \mathrm{df}=1\right.$, $\mathrm{P}=0.728$, likelihood ratio test of the year regression versus intercept only regression) or first-hand and second-hand reports combined $\left(\chi^{2}=0.06, \mathrm{df}=1, \mathrm{P}=0.809\right.$, likelihood ratio test of the year regression versus an intercept only regression).

\section{DISCUSSION}

Despite the removal of known hoaxes, the reports cannot necessarily be assumed to be accurate or indeed true. Nevertheless, even if not true or accurate, they still might reflect the zeitgeist and expectations by the witnesses. Distinguishing the witnesses' intent in describing their reports is difficult. For example, an encounter can be described as being with a sea serpent but this may or may not imply the witness thought the body shape was actually serpentine. Here we only characterised reports as serpentine if the body shape was explicity described as serpentine as opposed to the encounter merely being described as a 'sea serpent' encounter. Some witnesses clearly did distinguish between serpentine bodyforms and other bodyforms but we cannot be 
certain all did. Indeed, some may have seen them as essentially similar. In Journey to the Centre of the Earth (1874, p. 202), Verne's American translator described the plesiosaur as a "monstrous serpent, concealed under the hard vaulted shell of a turtle". If Verne had actually reported a sea serpent would he have distinguished between a plesiosaur-shaped animal and a serpentiform one?

Nevertheless, despite the problems inherent in determining the intent of witnesses, if overall there was a decline in the number of potential witnesses with an a priori picture in mind of a serpentine sea serpent then this should be reflected in the statistics. A genuine decline in serpentine reports is indeed evident over the last 200 years. Likewise, there is evidence over 200 years for an increase in 'necked' sightings. However, there is no evidence for an increase in general reptilian reports as might be expected if mosasaur discoveries were influencing witnesses. This may reflect a relative lack of public awareness of mosasaurs as opposed to other Mesozoic marine reptiles as indicated by the late suggestion for mosasaurs as sea serpents in 1892/1901.

Do these trends support de Camp's (1968) hypothesis? They probably do, but perhaps not over the timespan to which he was referring. There is no evidence of a sudden change in the nature of the reports in the middle part of the nineteenth century (Figure 3). Whilst interpreters of sea serpent reports invoked prehistoric reptiles early in the nineteenth century, witnesses with the sole exception of Foley in 1835, did not definitively mention them until the late nineteenth century and even then rather infrequently. Furthermore, other possible explanations for the observed trend should be considered, especially given the lack of increase in the other classes of body description. If it is assumed that De Camp's hypothesis extends to the twentieth century, more space for publication may have allowed more elaborate description with what was seen, perhaps leading to a decline in serpentiform reports as witnesses could become more verbose (or be quoted more fully) and make further colorful comparisons. This might also cause an increase in sightings where a neck is mentioned or pictured.

The existence of trends in the reports is ambiguous with regard to the hypotheses that there are actual unknown giant serpentiform or long necked giant marine animals. In his compedium of 587 sea serpent reports, Heuvelmans (1968) identified some putative 'species' of sea serpent and noted that some of the more serpentiform ones now seemed rare. He further reckoned that one of his hypothesised types of sea serpent - the 'long-necked seal'-was becoming more common (although he gave no numbers to justify this claim). Our results, based on considerably more data and a more formally quantitative approach, are similar but we would argue that any trends in the reports should be recognised as trends in the reports rather than as trends in the actual populations of unknown animals (after Paxton 2010), and that ideas on changes of what is reported should initially consider sociological influences on the witnesses. If the reports were generated from actual observations of mystery animals, a consistent trend would seem unlikely. This would imply a consistent population trajectory over 200 years, or that increasing numbers of observers were moving into environments where such animals are found (or moving out of them, in the case of a decrease in reports).

A strong qualitative case can be made that science has influenced writers (Eichner 1982; Seed 2003; Alt 2010), artists (Henderson 2008) and even poets (Bay-Petersen 1985). Moreover, the influence of contemporary geological and marine biological discoveries can be readily discerned in such nineteenth century 'sea monster' fictions such as Moby Dick (Melville 1851), Voyage au Centre de la Terre (Verne 1864), Vingt Mille Lieues sous les Mers (Verne 1870) and The Sea Raiders (Wells 1896). Demonstrating an influence on the perceptions of the wider public is, however, rather more difficult, although book sales and library subscriptions may provide some relevant evidence. Whilst the consequences of new technology are often readily apparent, more subtle cultural perceptions are difficult to document. This is especially the case when no opinion polls are available. Sea monster witnesses are a biased sample of the general public but there is no reason to believe that witnesses should be biased with regard to chronological changes in their palaeontological knowledge. If the changes in report proportions discussed above were not the result of greater space to write, nor reflective of a greater emphasis on direct quoting of twentieth century witnesses, then it does appear that witnesses were influenced by palaeontological 


\section{G. M. PAXTON AND D. NAISH}

discoveries, albeit perhaps over a longer period of time than de Camp (1968) ambiguously suggested. More data collection may allow further light to be shed on this process.

\section{ACKNOWLEDGEMENTS}

Thanks to Matt Salusbury for suggesting the Crystal Palace dinosaurs as a source of marine reptile popularity, Richard Fallon for information on nineteenth century texts and Adrian Shine, Valentin Popov, Jeremy Greenwood, David Spalding and an anonymous referee for comments on the manuscript.

\section{REFERENCES}

Alt, C., 2010. Virginia Woolf and the Study of Nature. Cambridge: Cambridge University Press.

Altick, R. 1957. The English Common Reader: A Social History of the Mass Reading Public, 1800-1900. Chicago: Chicago University Press

Anonymous. 1829. Untitled. The Times 20 February 1829, p. 3.

Anonymous. 1848a. The great sea serpent. The Times 10 October 1848 , p. 5.

Anonymous. 1848b. The great sea serpent. Illustrated London News 28 October 1848, p. 264.

Anonymous. 1858. Letter. The Times February 16th 1858, p. 10

Anonymous. 1873. More news. Manitowoc Tribune 17 July 1873 p. 1.

Anonymous. 1882. The British Association. The Times 30 August 1909, p. 7.

Anonymous. 1891. Monsters of the past. The Morning Call 18 October 1891, p. 15.

Anonymous. 1894. A seventy-foot dragon. Orange County Observer 14 April 1894, p. 4.

Anonymous. 1896. Big sea serpents. Wilmington Daily Republican 18 July 1896, p. 4

Bakewell, R. 1833a. Introduction to Geology, 4th edition. London: Longman, Rees, Orne, Browne, Green and Longman.

Bakewell, R. 1833b. Introduction to Geology, 2nd American edition. New Haven: Hezekiah Howe \& Co.

Batchelor, G. (1913). Letter in Heuvelmans, B. 1968. In the Wake of the Sea-Serpents, 393-394. New York: Hart-Davis.

Bay-Petersen, O. 1985. T. S. Eliot and Einstein, the fourth dimension in the Four Quartets. English Studies 2: $143-155$.

Bowbell. 1849. The sea serpent in a fog. Punch 16: 167.

Cogswell, C. 1848. The great sea-serpent. The Zoologist 6: 2316-2323.

Conybeare, W. D. 1824. On the discovery of an almost perfect skeleton of the Plesiosaurus. Transactions of the Geological Society of London Series 2, Volume 1: 382-389.

Davison, A. C. and Hinckley, D. V. 1997. Bootstrap Methods And Their Application. Cambridge: Cambridge University Press

De Camp, L. S. 1968. Dinosaurs in today's world. The Magazine of Fantasy and Science Fiction 34(3): 6880.

De Camp, L. S. 1983. The Fringes of the Unknown. Buffalo, New York: Prometheus.

De la Beche, H. T. 1833. A Geological Manual. London: Treuttel and Würtz.

Doyle, P., and Robinson, E. 1993. The Victorian 'Geological Illustrations' of Crystal Palace Park. Proceedings of the Geologists' Association 104: 181-194.

Drummond, E. 1848. The great sea-serpent. The Zoologist 6: 2306-2307.

DSE. 1848. Letter to Bucks Herald 9 December 1848, p. 7.

Eichner, H. 1982. The rise of modern science and the genesis of romanticism. Proceedings of the Modern Language Association 97: 8-30.

Ellis, R. 2003. Sea Dragons: Predators of Prehistoric Oceans. Lawrence: University Press of Kansas.

Evans, M. 2010. The roles played by museums, collections and collectors in the early history of reptile palaeontology. In: Dinosaurs and Other Extinct Saurians: A Historical Perspective edited by R. T. J. Moody, E. Buffetaut, D. Naish and D. M. Martill, 5-29. Geological Society, London, Special Publications 34.

F.G.S. 1848. Letter to The Times 2 November 1848, p. 3.

Figuer, G. L. 1863. La terre avant le deluge. Paris: Hatchette.

Foley, W. 1835. An unusual sea-monster in the bay. Journal of the Asiatic Society of Bengal 4: 62-63.

Foley, W. 1836. Sea monster in the bay of Bengal. Carroll Free Press, 2 September 1836, p. 1. 


\section{SEA SERPENT REPORTS}

Galbreath, G. J. 2015. The 1848 'enormous serpent' of the Daedalus identified. Skeptical Inquirer 35(5): 42-46.

Gosse, P. H. 1862. The Romance of Natural History. Second series. London: James Nisbet.

Gould, R. T. 1930. The Case for the Sea Serpent, $1^{\text {st }}$ edition. London: Philip Allan.

Harlan, R. 1834. Notice of fossil bones found in the Tertiary formation of the state of Louisiana. Transactions of the American Philosophical Society 4: 397-403.

Hawkins, T. 1834. Memoirs of the Ichthyosauri and Plesiosauri. London: Rolfe and Fletcher.

Hawkins, T. 1840. Book of Great Sea Dragons. London: William Pickering.

Henderson, L. D. 2008. Einstein and 20th century art: A romance of many dimensions. In: Einstein for the 21st Century: His Legacy in Science, Art and Modern Culture, edited by P. L. Galison, G. Holton and S. S. Schwebe, 101-129. Princeton: Princeton University Press,

Heuvelmans, B. 1968. In the Wake of the Sea-Serpents. New York: Hart-Davis.

Howe, S. R., Sharpe, T., and Torrens, H. S. 1993. Ichthyosaurs: A History of Fossil 'Sea-Dragons'. Cardiff: National Museum of Wales.

Hutchinson, H. N. 1892. Extinct Monsters, $2^{\text {nd }}$ edition. London: Chapman \& Hall.

Lawrence, A. (1884). Letter in Heuvelmans, B. 1968. In the Wake of the Sea-Serpents, 266. New York: HartDavis.

Lomax, D. R., and Trevelyan, J. 2010. Whitby Museum. Deposits 23: 7. https://epositsmag.com/2016/ 02/02/whitbys-fossil-history-and-museum/

Loxton, D., and Prothero, D. R. 2013. Abominable Science. New York: Columbia University Press.

Lucas, F. A. 1901. Animals of the Past. New York: Maclure, Phillips \& Co.

Lyons, S. L. 2010. Species, Serpents, Spirits, and Skulls: Science at the Margins in the Victorian Age. New York: State University of New York Press.

McGowan, C. 1991. The Dragon Seekers. London: Abacus.

Melville, H. 1851. Moby Dick. New York: Harper and Brothers.

Morries-Stirling, J. D. 1848. Letter to Illustrated London News 28 October 1848: 265-266.

Mulder, E. W. A. 2004. Maastricht Cretaceous finds and Dutch pioneers in vertebrate palaeontology. In: Dutch Pioneers of the Earth Sciences edited by J. L. R. Touret and R. P. W. Visser Royal, 165-176. Amsterdam: Netherlands Academy of Arts and Sciences,

Myrone, M. 2011. John Martin Apocalypse. London: Tate.

Naish, D. 2017. Hunting Monsters. London: Acturus.

Naturalist. 1848. Letter to The Times 10 November 1848: 6.

Newman, E. 1849. Enormous undescribed animals, apparently allied to the Enaliosauri, seen in the Gulf of Califormia. Zoologist 7: 2356.

OECD. 2018. "Education GPS." Retrieved 3/5/2018, from http://gpseducation.oecd.org.

Oudemans, A. C. 1892. The Great Sea Serpent. London: Luzac and Co.

Owen, R. 1839. Observations on the Basilosaurus of Dr. Harlan (Zeuglodon cetoides). Transactions of the Geological Society of London 6: 69-79.

Owen, R. 1848. The sea serpent. The Times, 14 November 1848: 8.

Paxton, C. G. M. 2009. The plural of 'anecdote' can be 'data': Statistical analysis of viewing distances in reports of unidentified large marine animals 1758-2000. Journal of Zoology 279: 381-387. https://doi.org/10.1111/j.1469-7998.2009.00630.x

Paxton, C. G. M. 2010. The monster manual. Fortean Times 265: 54.

Paxton, C. G. M., and Shine, A. J. 2016. Consistency in eyewitness reports of anomalies: Examples from accounts of aquatic "monsters". Journal of Scientific Exploration 30: 16-26.

ФI $\Lambda \mathrm{O} \Sigma \mathrm{ATPO} \Sigma$ 1834. Letter to The Times 21 November 1834, p. 4.

Reippell, L. 2017. Albert Koch's Hydrarchos craze: Credibility, identity, and authenticity in nineteenthcentury natural history. In: Science Museums in Transition: Cultures of Display in Nineteenth-Century Britain and America, edited by C. Berkowitz and B. Lightman, 139-161. Pittsburgh: University of Pittsburgh

Rudwick, M. J. S. 1992. Scenes from Deep Time. London: University of Chicago.

Seed, D. 2003. H. G. Wells and the liberating atom. Science Fiction Studies 30(1): 33-48.

Spamer, E. E., Daeschler, E., and Vostreys-Shapiro, L. G. 1995. A study of fossil types in the Academy of Natural Science of Philadelphia. The Academy of Natural Science Special Publication 16.

Taylor, M. A. 2016. 19th century plaster casts of Lower Jurassic ichthyosaurs and plesiosaurs in the Bristol Institution for the Advancement of Science, Literature and the Arts, and the Academy of Natural Sciences, Philadelphia. The Geological Curator 10(8): 277-281. 
Van Derwoort, J. W. 1884. The Water World. New York: Union.

Verne, J. 1864. Voyage au centre de la Terre. Paris: J. Hetzel.

Verne, J. 1872. Journey to the Centre of the Earth. London: Griffith \& Farran.

Verne, J. 1874. Journey to the Centre of the Earth. London and New York: Scribner Armstrong. Wells, H .G. 1896. The sea raiders. The Weekly Sun Literary Supplement, 6 December 1896.

Wyman, J. 1848. Communication. Proceedings of the Boston Society of Natural History 2: 65-68. Yee, T. W. 2008. The VGAM package. $R$ News 8: 28-39. 